\title{
MECHANICAL PROPERTIES OF LAMINATED VENEER LUMBER BEAMS STRENGTHENED WITH CFRP SHEETS
}

\begin{abstract}
M. BAKALARZ ${ }^{1}$, P. G. KOSSAKOWSKI ${ }^{2}$
This paper presents the results of the static work analysis of laminated veneer lumber (LVL) beams strengthened with carbon fabric sheets (CFRP). Tested specimens were $45 \mathrm{~mm}$ wide, $100 \mathrm{~mm}$ high, and $1700 \mathrm{~mm}$ long. Two types of strengthening arrangements were assumed as follows: 1 . One layer of sheet bonded to the bottom face; 2. U-shape half-wrapped reinforcement; both sides wrapped to half of the height of the cross-section. The reinforcement ratios were $0.22 \%$ and $0.72 \%$, respectively. In both cases, the FRP reinforcement was bonded along the entire span of the element by means of epoxy resin. The reinforcement of the elements resulted in an increase in the bending strength by $30 \%$ and $35 \%$, respectively, as well as an increase in the global modulus of elasticity in bending greater than $20 \%$ for both configurations (in comparison to the reference elements).
\end{abstract}

Keywords: carbon fibres, LVL, strengthening, timber structures,

\section{INTRODUCTION}

The basic treatments aimed at rehabilitating or strengthening existing [3, 4] and new structural elements include the change of the static scheme, the addition of a cooperating structure, and the introduction of additional materials. Steel and composite materials are most often used as an additional material. With regard to wooden structures, composite materials are used both as:

\footnotetext{
${ }^{1}$ MSc., Eng., Kielce University of Technology, Faculty of Civil Engineering and Architecture, Al. Tysiąclecia Państwa Polskiego 7, 25-314 Kielce, Poland, e-mail: mbakalarz@tu.kielce.pl

${ }^{2}$ DSc., PhD., Eng., Prof. KUT, Kielce University of Technology, Faculty of Civil Engineering and Architecture, Al. Tysiąclecia Państwa Polskiego 7,

25-314 Kielce, Poland, e-mail: kossak@tu.kielce.pl
} 
external reinforcement [9], in most cases glued with epoxy resin adhesives or attached by means of mechanical fasteners [5]; or as internal reinforcement glued into previously prepared grooves [11, $12,18]$. The second solution allows the design to hide the material inside the outline of the crosssection, thus maintaining the original appearance of the element and securing the combination of the wood-glue-composite against the external factors.

In the case of bending wooden beams, the reinforcement is located mainly in the tensile zone, which results from the shortage of tensile strength in relation to compressive strength. However, the best results of the increase in bending strength and cross-section stiffness are achieved by using reinforcement in both zones [13]. The most often used composite materials are fabric sheets [1,14], laminates $[6,22]$, and rods $[8,21]$ reinforced with:

- Carbon fibres (Carbon Fibre Reinforced Polymer);

- Glass fibres (Fibre Reinforced Polymer);

- Aramid fibres (Aramid Fibre Reinforced Polymer);

- Basalt fibres [7] (Basalt Fibre Reinforced Polymer).

\section{MATERIALS AND METHODOLOGY}

\subsection{LAMINATED VENEER LUMBER}

Tests were conducted on the given specimens in a laboratory environment. The specimens were $45 \mathrm{~mm}$ wide and $100 \mathrm{~mm}$ tall. The nominal length of the beams was $1700 \mathrm{~mm}$ and $1600 \mathrm{~mm}$ at the support axis. Table 1 provides the information about the mechanical properties of the LVL used.

Table 1. Selected parameters of laminated veneer lumber

\begin{tabular}{|c|c|}
\hline Parameter & Edgewise condition \\
\hline Bending strength $\left(\mathrm{N} / \mathrm{mm}^{2}\right)$ & 44 \\
\hline Tensile strength $\left(\mathrm{N} / \mathrm{mm}^{2}\right)$ & 46 \\
\hline Compression strength parallel to the grains $\left(\mathrm{N} / \mathrm{mm}^{2}\right)$ & 4,6 \\
\hline Shear strength $\left(\mathrm{N} / \mathrm{mm}^{2}\right)$ & 14000 \\
\hline Modulus of elasticity $\left(\mathrm{N} / \mathrm{mm}^{2}\right)$ & 600 \\
\hline Shear modulus $\left(\mathrm{N} / \mathrm{mm}^{2}\right)$ & 480 \\
\hline Density $\left(\mathrm{kg} / \mathrm{m}^{3}\right)$ & 40 \\
\hline
\end{tabular}




\subsection{CARBON FIBRE REINFORCED FABRIC SHEETS}

As a reinforcement, unidirectional CFRP sheets - S\&P C-Sheet $240(600 \mathrm{~g} / \mathrm{m} 2)$ - were used. Prior to application, the fabric was tailored and saturated with epoxy resin. According to the manufacturer, the data sheet tensile strength and modulus of elasticity were $5100 \mathrm{MPa}$ and $265 \mathrm{GPa}$, respectively [18]. Technical parameters of the composite material are presented in Table 2.

Table 2. Selected parameters of carbon fabric sheet [19]

\begin{tabular}{|c|c|}
\hline Parameter & Carbon fabric sheets - S\&P C-Sheet $240\left(600 \mathrm{~g} / \mathrm{m}^{2}\right)$ \\
\hline Modulus of elasticity $\left(\mathrm{kN} / \mathrm{mm}^{2}\right)$ & $\geq 265$ \\
\hline Tensile strength $\left(\mathrm{N} / \mathrm{mm}^{2}\right)$ & $\geq 5100$ \\
\hline Fibre weight, longitudinal $\left(\mathrm{g} / \mathrm{m}^{2}\right)$ & 600 \\
\hline Weight per unit area of sheet $\left(\mathrm{g} / \mathrm{m}^{2}\right)$ & 630 \\
\hline Density $\left(\mathrm{g} / \mathrm{cm}^{3}\right)$ & 1,80 \\
\hline Elongation at rupture $(\%)$ & $\geq 1,7 \div 1,9$ \\
\hline Design thickness $(\mathrm{mm})$ & 0,333 \\
\hline
\end{tabular}

\subsection{EPOXY RESIN}

Fabric sheets were bonded to the external faces of the elements by means of epoxy resin - S\&P Resin 55 HP. The two-component epoxy resin was mixed with a low-speed drill with the recommended weight proportions. The faces of the laminated veneer lumber beams were ground and cleaned before the application of adhesive. The carbon sheets were saturated before wrapping. Adhesive parameters are available in the technical data sheet [20].

\subsection{TEST PROCEDURE}

Bending strength and global modulus of elasticity were determined with accordance to standards $[16,17]$. The isotropic material model was applied [15]. The specimens were tested on a universal hydraulic machine in the so-called 4-point bending static scheme. The loading rate was set to 7 $\mathrm{mm} / \mathrm{min}$. The scheme of the static test setup is presented in Fig. 1. 


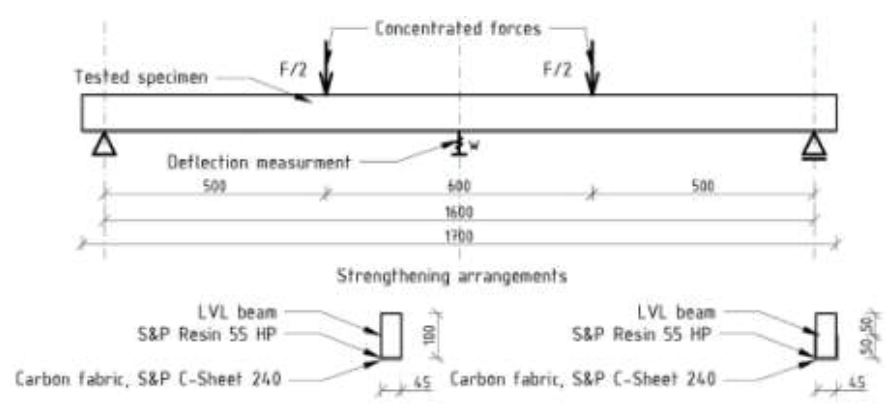

Fig. 1. Scheme of the static test setup

Three sets of specimens were prepared for the test as follows: LVL series - reference beams; LVLC series - beams strengthened with one layer of fabric sheet bonded to the bottom face $(\rho=0,22 \%)$; LVLCU series - beams strengthened with a fabric sheet wrapped around the bottom and both sides of the elements, (the U-shaped half-wrapped type ; $\rho=0,72 \%$ ).

During bending tests the loading force, test time, and midspan deflection were continuously measured. After testing, failure modes were noted and parameters determined. Bending strength in edgewise conditions was determined on the basis of the following equation [16]:

$$
f_{m}=\frac{3 F a}{b h^{2}}
$$

where:

$\alpha$ - distance between support and the closest loading point, $\mathrm{F}$ - maximum loading force, $\mathrm{b}$ - width of crosssection, $\mathrm{h}$ - height of cross-section.

In next step, the bending strength determined according to Eq. (2.1) was corrected to the reference height by multiplying it by the coefficient determined from the following equation [16]:

$$
k_{m, \text { corr }}=\left(\frac{b}{300}\right)^{s}
$$

where:

$\mathrm{s}$ - shape parameter determined from the following formula $2 \mathrm{v}-0.05, \mathrm{v}-$ coefficient of variation $(0,15), \mathrm{b}-$ width of the laminated veneer lumber. 
The global modulus of elasticity in bending was determined according to the equation [15]:

$$
E_{m, \mathrm{~g}}=\frac{3 a l^{2}-4 a^{3}}{2 b h^{3}\left(2 \frac{w_{2}-w_{1}}{F_{2}-F_{1}}-\frac{6 a}{5 G b h}\right)}
$$

where:

$\mathrm{F}_{2}-\mathrm{F}_{1}$ - increment of the loading force in linear phase of load versus deflection curve, $\mathrm{w}_{2}-\mathrm{w}_{1}-$ increment of the deflection corresponding to the force increment, $\mathrm{G}$ - shear modulus (600MPa).

\section{TEST RESUlts}

The behaviour of the beams during the four-point bending test is shown in the graphs illustrating the dependence of the loading force on the deflection and duration of the test (Fig. 2, 3). A detailed list of registered parameters is presented in Tables 3 and 4 .

The course of the curves (which show the way the reference beams behave) can be described as rectilinear until the breaking force is reached; it is then followed by a load drop and cross-section strengthening. However, for strengthened beams, one can see an increase in ductility, which is identified with a greater use of the compression zone of the cross-section. In these elements no strengthening of the cross-section was noted after reaching the maximum force - it was subject to slow destruction (Fig. 2).

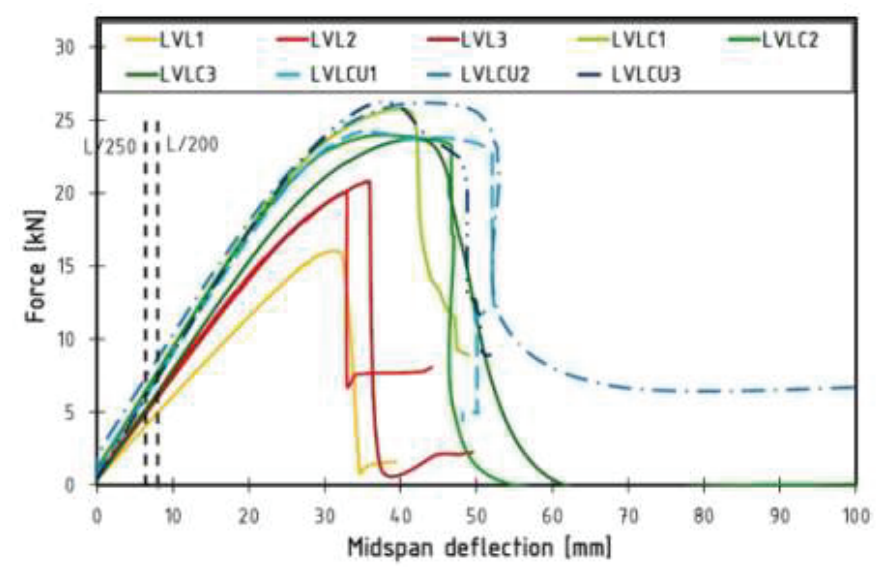

Fig. 2. Load versus deflection curves for tested specimens 
At a fixed loading rate equal to $7 \mathrm{~mm} / \mathrm{min}$, the force leading to the destruction occurred at the time recommended by the standard [16] for all tested specimens (Fig. 3).

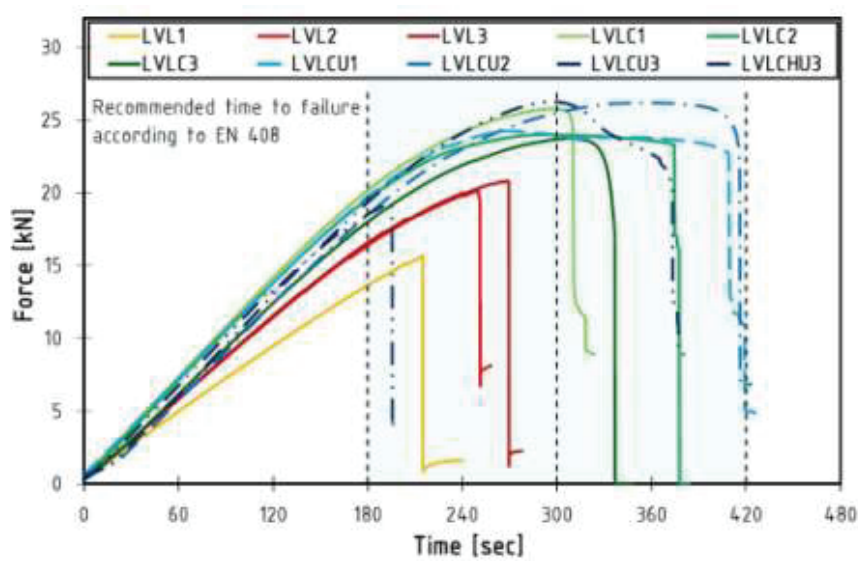

Fig. 3. Load versus time curves for tested specimens

The reference beams were destroyed abruptly due to a crack in the tensile zone - the zone of the maximum moment. Strengthened elements were characterized by a greater diversity of failure modes. In the case of elements reinforced with one layer bonded to the bottom face, failure resulted when the load-bearing capacity in the compression zone (LVLC1) was exceeded, when shear failure was initiated in the anchorage zone (LVLC2), and an interruption of continuity over the entire cross-sectional height was noted (LVLC3). For elements of the LVLCU series, a typical behaviour noted was the interruption of the carbon fabric combined with the deformations of the zone of the compressed cross-section.

Results of the experimental tests (maximum loading force, time to failure, and deflection at failure) as well as parameters determined according to Eq. (2.1-2.3) are presented in Table 3. 
LVL1 LVL2 LVL3

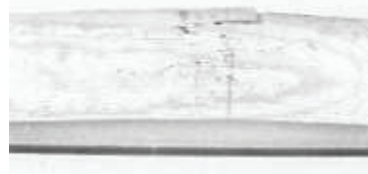

LVLC1

LVLC2

LVLC3
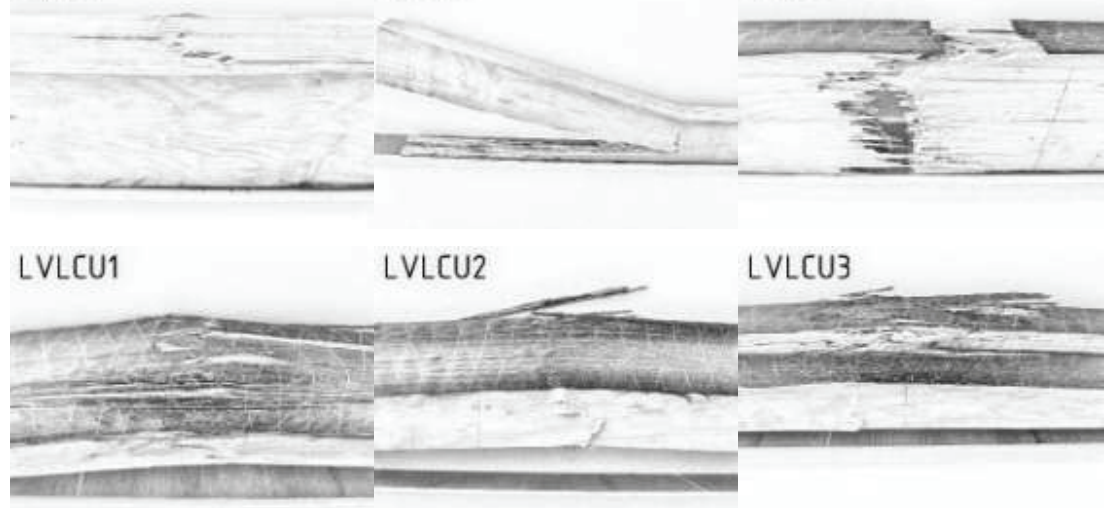

Fig. 4. Failure modes of tested specimens

Table 3. Results of experimental test

\begin{tabular}{|c|c|c|c|c|c|}
\hline Beam & $\begin{array}{c}\text { Maximum load } \\
{[\mathrm{kN}]}\end{array}$ & $\begin{array}{c}\text { Deflection at } \\
\text { failure } \\
{[\mathrm{mm}]}\end{array}$ & $\begin{array}{c}\text { Time to } \\
\text { failure } \\
{[\mathrm{sec}]}\end{array}$ & $\begin{array}{c}\text { Bending strength } \\
{[\mathrm{MPa}]}\end{array}$ & $\begin{array}{c}\text { Modulus of elasticity } \\
{[\mathrm{GPa}]}\end{array}$ \\
\hline LVL1 & 15,64 & 28,73 & 215 & $52,15\left(39,62^{*}\right)$ & 11,20 \\
\hline LVL2 & 20,14 & 32,86 & 250 & $67,14\left(51,01^{*}\right)$ & 14,09 \\
\hline LVL3 & 20,83 & 35,86 & 269 & $69,44\left(52,76^{*}\right)$ & 14,08 \\
\hline LVLC1 & 25,76 & 39,96 & 298,3 & $85,87\left(65,25^{*}\right)$ & 17,21 \\
\hline LVLC2 & 23,98 & 37,77 & 296,3 & $79,95\left(60,75^{*}\right)$ & 17,01 \\
\hline LVLC3 & 23,74 & 41,59 & 307,8 & $79,12\left(60,12^{*}\right)$ & 15,53 \\
\hline LVLCU1 & 24,23 & 35,32 & 269,3 & $80,78\left(61,38^{*}\right)$ & 16,72 \\
\hline LVLCU2 & 26,18 & 43,30 & 355,6 & $87,27\left(66,31^{*}\right)$ & 16,91 \\
\hline LVLCU3 & 26,27 & 37,65 & 296,0 & $87,56\left(66,53^{*}\right)$ & 17,49 \\
\hline & $*$ Values corrected to the reference height. & \\
\hline
\end{tabular}


Beams reinforced with carbon fabric sheets achieved a significant increase in bending strength equalling $30 \%$ for reinforcement bonded to the bottom surface and $35 \%$ for U-shaped half-wrapped reinforcement. For both tested series, an over $20 \%$ increase in the modulus of elasticity was also noted (Table 4). Comparing the values for flexural strength and modulus of elasticity of the individual series, it can be stated that the scatter of results obtained for reinforced elements in relation to control beams is smaller.

Table 4. Statistical analysis

\begin{tabular}{|c|c|c|c|c|c|c|}
\hline \multirow{2}{*}{ Series } & \multicolumn{3}{|c|}{ Bending strength [MPa] } & \multicolumn{3}{c|}{ Modulus of elasticity in bending [GPa] } \\
\cline { 2 - 7 } & Arithmetic mean & $\begin{array}{c}\text { Standard } \\
\text { deviation }\end{array}$ & $\begin{array}{c}\text { Coefficient of } \\
\text { variation }\end{array}$ & $\begin{array}{c}\text { Arithmetic } \\
\text { mean }\end{array}$ & $\begin{array}{c}\text { Standard } \\
\text { deviation }\end{array}$ & $\begin{array}{c}\text { Coefficient of } \\
\text { variation }\end{array}$ \\
\hline LVL & $62,91\left(47,80^{*}\right)$ & 7,67 & 0,12 & 13,12 & 1,17 & 0,10 \\
\hline LVLC & $\begin{array}{c}81,65\left(62,25^{*}\right) \\
(+30 \%)\end{array}$ & 3,00 & 0,04 & $\begin{array}{c}16,58 \\
(+24 \%)\end{array}$ & 0,62 & 0,04 \\
\hline LVLCU & $\begin{array}{c}85,21\left(64,75^{*}\right) \\
(+35 \%)\end{array}$ & 3,13 & 0,04 & $\begin{array}{c}17,04 \\
(+27 \%)\end{array}$ & 0,27 & 0,02 \\
\hline \multicolumn{7}{|c|}{ *Values corrected to the reference height. } \\
\hline
\end{tabular}

\section{SUMMARY}

This papers presents the results of the analysis of static work of laminated veneer lumber reinforced with carbon fabric sheets under a 4-point bending test. The experimental data revealed:

1. Reinforcement of the tensile zone of the LVL beams with carbon fabric sheets resulted in an increase in both the bending strength and the stiffness. The average increase in bending strength was $30 \%$ for reinforcement applied to the bottom face and $35 \%$ for $U$-shape reinforcements. The MOE in bending increased over $20 \%$ when compared to the unstrengthened elements.

2. Strengthened elements show increased ductility and their results were less variable in comparison to the unstrengthened elements.

3. The failure of the elements strengthened with the carbon sheet bonded to the bottom face resulted from the loss of strength of the laminated veneer lumber.

4. For the U-shape type of reinforcement, the failure was caused by a rupture of the carbon sheets and through exceeding the compressive strength parallel to the grains.

On the basis of the abovementioned results and the results of the tests presented in [2], it can be concluded that the effectiveness of strengthening LVL beams with CFRP sheets is higher than with the use of AFRP and GFRP sheets. 


\section{REFERENCES}

1. K. Andor, A. Lengyel, R. Polgár, T. Fodor, Z. Karácsonyi, "Experimental and statistical analysis of spruce timber beams reinforced with CFRP fabric" Construction and Building Materials 99: 200-207, 2015. 10.1016/j.conbuildmat.2015.09.026.

2. M. Bakalarz, P. Kossakowski, "The flexural capacity of laminated veneer lumber beams strengthened with AFRP and GFRP sheets" Technical Transactions 2. Civil Engineering: 85-96, 2019.

3. H. Biscaia, C. Chastre, D. Cruz, N. Franco, "Flexural Strengthening of Old Timber Floors with Laminated Carbon Fiber-Reinforced Polymers", Journal of Composites for Construction 20: 04016073, 2017. 10.1061/(ASCE)CC.1943-5614.0000731.

4. A. Borri, M. Corradi, "A method for flexural reinforcement of old wood beams with CFRP materials", Composites Part B 36: 143-153, 2005.

5. A. Borri, M. Corradi, G. Castori, "Reinforcement of softwoods beams using unglued composite laminates", Wiadomości konserwatorskie 47: 30-39, 2016.

6. A.M.P. De Jesus, J.M.T. Pinto, J.J.L. Morais, "Analysis of solid wood beams strengthened with CFRP laminates of distinct lengths", Construction and Building Materials 35: 817-828, 2012.

7. P. De La Rosa García, A. Cobo Escamilla, M. González García, "Bending reinforcement of timber beams with composite carbon fiber and basalt fiber materials", Composites Part B: Engineering 55: 528-536, 2013. 10.1016/j.compositesb.2013.07.016.

8. L. De Lorenzis, V. Scialpi, A. La Tegola, "Analytical and experimental study on bonded-in CFRP bars in glulam timber”, Composites Part B 36: 279-289, 2005.

9. I. Glišović, B. Stevanović, M. Todorović, T. Stevanović, "Glulam beams externally reinforced with CFRP plates", Wood Research 61(1): 141-154, 2016.

10. https://www.steico.com/index.php? $\mathrm{id}=73 \& \mathrm{~L}=3$, (access: 10.12 .2018 )

11. J. Jasieńko, T. Nowak, ”Wzmacnianie zginanych belek drewnianych obiektów zabytkowych przy użyciu taśm węglowych", V Konferencja Naukowa: Drewno i materiały drewnopochodne w konstrukcjach budowlanych, Szczecin 2002.

12. J. Jasieńko, T. Nowak, T. Rapp, ”Analiza pracy statycznej belek drewnianych wzmocnionych taśmami CFRP", Wiadomości konserwatorskie 26: 314-324, 2009.

13. R. Kliger, M. Al-Emrani, M. Johansson, R. Crocetti, "Strengthening glulam beams with steel or CFRP plates", Asia-PacificConf. on FRP in Structures (APFIS2007), International Institute for FRP in Construction, ON, Canada, 291-296, 2007.

14. P. Kossakowski, "Load-bearing capacity of wooden beams reinforced with composite sheets" (Nośność belek drewnianych wzmocnionych matami kompozytowymi). Structure \& Environment 3 (4): 14-22, 2011.

15. P.G. Kossakowski, "Influence of anisotropy on the energy release rate $G_{I}$ for highly orthotropic materials", Journal of Theoretical and Applied Mechanics, 45: 739-752, 2007.

16. PN-EN 408+A1:2012 Timber structures. Structural timber and glued laminated timber. Determination of some physical and mechanical properties.

17. PN-EN 14374:2005 Timber structures. Structural laminated veneer lumber (LVL). Requirements.

18. J. Sena-Cruz, M. Jorge, J.M. Branco, V.M.C.F. Cunha, "Bond between glulam and NSM CFRP laminates", Construction and Building Materials 40: 260-269, 2013.

19. Technical data sheet S\&P C-Sheet 240, http://www.sp-reinforcement.pl/pl-PL/produkty/maty/sp-c-sheet-240 (access: 10.12.2018)

20. Technical data sheet S\&P Resin 55 HP, http://www.sp-reinforcement.pl/pl-PL/produkty/zywicaepoksydowa/sp-resin-55-hp (access: 10.12.2018)

21. H. Yang, D. Ju, W. Liu, W. Lu, "Prestressed glulam beams reinforced with CFRP bars", Construction and Building Materials 109: 73-83, 2016.

22. A. Yusof, A.B. Rahman, "Flexural Strengthening of Timber Beams Using Carbon Fibre Reinforced Polymer", International Journal of Applied Engineering Research 12(3): 348-358, 2017.

\section{LIST OF FIGURES AND TABLES:}

Fig. 1. Scheme of the static test setup

Rys. 1. Schemat stanowiska badawczego

Fig. 2. Load versus deflection curves for tested specimens

Rys. 2. Wykres zależności "obciążenie - ugięcie" dla przebadanych elementów 
Fig. 3. Load versus time curves for tested specimens

Rys. 3. Wykres zależności "obciążenie - czas" dla przebadanych elementów

Fig. 4. Failure modes of tested specimens

Rys. 4. Postaci zniszczenia przebadanych elementów

Tab. 1. Selected parameters of laminated veneer lumber (LVL) [9]

Tab. 1. Wybrane parametry techniczne forniru klejonego warstwowo [9]

Tab. 2. Selected parameters of carbon fabric sheet [17]

Tab. 2. Wybrane parametry techniczne mat kompozytowych [17]

Tab. 3. Results of experimental test

Tab. 3. Wyniki badań eksperymentalnych

Tab. 3. Statistical analysis of the test results

Tab. 3. Analiza statystyczna wyników badań

\section{WŁaśCIWOŚCI MECHANICZNE BELEK Z FORNIRU KLEJONEGo WARSTWOWO WZMOCNIONYCH MATAMI CFRP}

Slowa kluczowe: LVL, konstrukcje drewniane, włókna węglowe, wzmacnianie

\section{STRESZCZENIE:}

W pracy przedstawiono wyniki analizy pracy statycznej belek z forniru klejonego wzmocnionych matami węglowymi (CFRP) przyklejonymi do zewnętrznej powierzchni elementu. Belki o wymiarach 45x100x1700mm poddane zostały tzw. czteropunktowemu zginaniu. Przyjęto dwie konfiguracje zbrojenia: jedna warstw maty CFRP przyklejona do powierzchni dolnej elementu na całej jego długości oraz zbrojenie typu U - kompozyt obejmuję powierzchnie boczne do połowy wysokości przekroju poprzecznego i dolną strefy rozciąganej. Stopień zbrojenia przekroju poprzecznego wynosił odpowiednio $0,22 \%$ i $0,72 \%$. W obu konfiguracjach do aplikacji wzmocnienia użyto kleju na bazie żywicy epoksydowej. Wzmocnienie elementów spowodowało wzrost nośności na zginanie przeciętnie o 30 i 35\% oraz globalnego modułu sprężystości przy zginaniu o ponad $20 \% \mathrm{~W}$ stosunku do belek referencyjnych (niewzmocnionych). Wyniki analizy wykazały także duże zróżnicowanie w postaciach zniszczenia elementów wzmocnionych jedną warstwą maty. Sposób zniszczenia elementów dla drugiej konfiguracji wzmocnienia został ujednolicony do jednego typu - zniszczenia spowodowane wyczerpaniem nośności w strefie ściskanej i przerwaniem maty kompozytowej.

Received 17.12.2018

Revised 30.06.2019 